\title{
KOMPENSASI, DISIPLIN KERJA, DAN MOTIVASI KERJA BERPENGARUH TERHADAP PRODUKTIVITAS KARYAWAN JIMBARAN BAY SEAFOOD CAFÉ KEDONGANAN
}

\author{
I Made Krisna Suryantika ${ }^{1}$ \\ I Made Artha Wibawa ${ }^{2}$ \\ ${ }^{1,2}$ Fakultas Ekonomi dan Bisnis Universitas Udayana (Unud), Bali, Indonesia \\ email: krisnasuryantika@gmail.com
}

\begin{abstract}
ABSTRAK
Sumber daya manusia merupakan salah satu faktor terpenting dalam perusahan untuk mencapai tujuan suatu perusahaan. Produktivitas karyawan merupakan kemampuan karyawan dalam menyelesaikan suatu pekerjaan secara efektif dan efisien yang telah ditetapkan oleh perusahaan untuk mencapai tujuan dari perusahaan. Produktivitas karyawan dapat dipengaruhi oleh beberapa faktor yaitu kompensasi, disiplin kerja, dan motivasi kerja. Penelitian ini dilakukan untuk menguji signifikansi pengaruh kompensasi, disiplin kerja, dan motivasi kerja terhadap produktivitas karyawan Jimbaran Bay Seafood Café Kedonganan Bali. 55 orang sampel digunakan, dengan metode sampel jenuh. Pengumpulan data melalui wawancara, dan kuisioner. Teknik analisis yang digunakan yaitu regresi linear berganda. Hasil analisis menunjukan bahwa kompensasi, disiplin kerja, dan motivasi kerja secara parsial berpengaruh positif dan signifikan terhadap produktivitas karyawan. Secara teoritis penelitian ini juga memberikan pemahaman bahwa kompensasi, disiplin kerja dan motivasi kerja secara nyata dapat meningkatkan produktivitas karyawan, dengan meningkatkan kompensasi, disiplin kerja dan motivasi kerja maka produktivitas karyawan akan mengalami peningkatan.
\end{abstract}

Kata kunci: kompensasi, disiplin kerja, dan motivasi kerja

\begin{abstract}
Human resources is one of the most important factors to achieve the goals of a company. Employee productivity is the ability of employees to complete a job effectively and efficiently. Employee productivity can be influenced by several factors, namely compensation, work discipline, and work motivation. This study was conducted to examine the significance of the effect of compensation, work discipline, and work motivation on employee productivity at Jimbaran Bay Seafood Café Kedonganan - Bali. 55 samples were used, with the saturated sample method. Data collection through interviews and questionnaires. The analysis technique used is multiple linear regression. The analysis showed that compensation, work discipline, and work motivation partially had a positive and significant effect on employee productivity. Theoretically this study also provides an understanding that compensation, work discipline and work motivation can significantly increase employee productivity, by increasing compensation, work discipline and work motivation, employee productivity will increase.

Keywords: compensation, work discipline, and work motivation
\end{abstract}




\section{PENDAHULUAN}

Keberhasilan suatu perusahaan dalam usaha mencapai tujuan ditentukan oleh kualitas sumber daya manusianya. Manusia merupakan salah satu faktor yang memegang peranan penting dalam membantu terwujudnya tujuan perusahaan karena masalah yang akhirnya menentukan dan memprediksikan keberhasilan atau kegagalan suatu kebijakan, strategi maupun langkah-langkah kegiatan operasional yang siap dilaksanakan. Upaya untuk meningkatkan kualitas sumber daya manusia perusahaan perlu dilakukan secara baik, terarah, dan terencana, karena sumber daya manusia sebagai salah satu unsur yang sangat menentukan keberhasilan suatu organisasi atau perusahaan. Hal ini sangat membutuhkan pendekatan khusus karena faktor-faktor tersebut akan menentukan dedikasi dan kinerja seorang karyawan sehingga karyawan tersebut akan memberikan kinerja yang lebih dari yang diharapkan oleh perusahaan sehingga produktivitas dari karyawan juga dinilai baik oleh perusahaan.

Produktivitas mengandung arti sebagai perbandingan antara hasil yang dicapai (output) dengan keseluruhan sumber daya yang digunakan (input). Dengan kata lain bahwa produktivitas memiliki dua dimensi. Dimensi pertama adalah efektivitas yang mengarah kepada pencapaian unjuk kerja yang maksimal yaitu pencapaian target yang berkaitan dengan kualitas, kuantitas, dan waktu yang kedua yaitu, efisiensi yang berkaitan dengan upaya membandingkan input dengan realisasi penggunaanya atau bagaimana pekerjaan tersebut dilakukan (Abomeh, 2015). Produktivitas karyawan merupakan hal yang penting dalam perusahaan, jika karyawan bekerja secara produktif maka perusahaan dikatakan berhasil meraih tujuan dan jika karyawan tidak bekerja secara produktif maka perusahaan dikatakan tidak berhasil meraih tujuan perusahaan (Dobre, 2018).

Produktivitas karyawan juga sangat ditentukan oleh kompensasi, motivasi dan disiplin kerja. Produktivitas pada hakikatnya merupakan suatu akibat dari persyaratan - persyaratan kerja yang harus dipenuhi oleh karyawan. Seorang karyawan dapat dikatakan produktif jika dalam waktu tertentu dapat menyelesaikan pekerjaan yang telah ditetapkan dan ditugaskan padanya. Pada dasarnya seorang karyawan harus memiliki sikap yang optimis yang berakar pada keyakinan bahwa hari esok harus lebih baik lagi dari hari ini serta harus didasarkan pada kemampuan dan keterampilan sesuai kompetensi serta harus didukung oleh disiplin kerja yang tinggi (Ruauw dkk., 2015)

Penelitian yang dilakukan di Jimbaran Bay Seafood Café Kedonganan memiliki masalah terkait dengan produktivitas karyawan, setelah dilakukannya wawancara terhadap pemilik Jimbaran Bay Seafood Café yaitu Bapak Ketut Suastana menyatakan bahwa karyawannya kurang berkerja secara maksimal ketika ramainya pengunjung yang datang, karyawan tidak dapat melaksanakan tugas yang telah diberikan dengan cepat melainkan menyelesaikan tugas yang telah diberikan dengan waktu yang cukup lama, seperti pada pelayanan, karyawan sering kebingungan dan merasa kewalahan ketika dibebankan dengan tugas yang menumpuk saat maraknya pengunjung yang berkunjung ke Jimbaran Bay Seafood Café, selain itu tugas yang dikerjakan tidak memiliki kualitas yang baik dan tidak sesuai harapan dari perusahaan, hal ini menyababkan pengunjung menjadi complain terhadap pelayanan yang telah diberikan oleh karyawan tersebut, selain 
itu karyawan juga biasanya lalai akan tugas yang telah diberikan ketika tidak ada pengawasan dari manajemen yang bertugas.

Peneliti melakukan wawancara terhadap 7 karyawan Jimbaran Bay Seafood Café yang juga membuktikan bahwa terdapat masalah pada produktivitas karyawan, dimana karyawan tersebut mengatakan bahwa hal yang menyebabkan kurang efektifnya pekerjaan yang dilaksanakan karena minimnya fasilitas yang ada seperti pada kasir, dimana pada kasir saat adanya pembayaran menggunakan credit card terkadang sulitnya mendapatkan sinyal yang menyebabkan lambatnya penanganan dalam sistem pembayaran melalui credit card, lalu pada bagian dapur, karyawan mengeluhkan permintaan yang terlalu banyak dibebankan kepada karyawan serta ramainya para tamu yang datang membuat para karyawan kesulitan dalam menanganinya.

Kompensasi merupakan salah satu faktor yang menyebabkan produktivitas karyawan bekerja. Kompensasi merupakan salah satu faktor yang sangat penting untuk mendapatkan hasil kerja atau meningkatkan kerja yang optimal. Kompensasi yang baik akan menciptakan kepuasan kepada karyawan, dan akan memotivasi karyawan untuk bekerja lebih baik (Negash \& Megersa, 2014). Sebaliknya, untuk memperoleh kompensasi yang lebih baik, karyawan akan berusaha bekerja lebih baik, ketika seorang karyawan merasakan kepuasan dalam bekerja, karyawan akan berusaha semaksimal mungkin dengan segenap kemampuannya untuk menyelesaikan pekerjaannya(Okwudili \& Ogbu, 2017). Kompensasi merupakan segala pendapatan yang berbentuk uang, barang langsung atau tidak langsung sebagai imbalan atas jasa yang diberikan kepada perusahaan terhadap karyawan (Emmywati \& Fatimah, 2018). Dengan produktivitas dan hasil kerja karyawan yang meningkat dapat mendorong tercapainya tujuan organisasi. Kompensasi yang efektif juga dapat membuat karyawan merasa dihargai atas kontribusi yang diberikan terhadap perusahaan. Dengan demikian karyawan akan bekerja dengan disiplin dalam bekerja.

Salah satu faktor yang menyebabkan terjadinya permasalahan produktivitas karyawan pada perusahaan yaitu dikarenakan kompensasi yang buruk. Pada Penelitian yang dilakukan di Jimbaran Bay Seafood Café terdapat masalah pada kompensasi yang diterima oleh karyawan, setelah dilakukannya wawancara terhadap 5 karyawan yang bekerja di Jimbaran Bay Seafood Café menyatakan bahwa kompensasi khususnya pada gaji yang diterima tidak sesuai dengan UMK Badung pada tahun 2019 yang telah ditetapkan yaitu Rp. 2.700.297 selain itu juga tunjangan transport yang tidak meningkat, hal tersebut menyebabkan karyawan bekerja dengan setengah hati sehingga menyebabkan produktivitas karyawan menurun.

Bahri \& Kamse (2018) menyatakan disiplin kerja karyawan merupakan salah satu hal yang harus diperhatikan untuk mencapai tujuan organisasi yang efektif dan efisien. Razak \& Ramlan (2018) menyatakan disiplin kerja adalah tindakan-tindakan yang diambil seorang manajer untuk menegakkan pedoman dan peraturan-peraturan orang itu. Disiplin kerja dapat dikatakan ketaatan di dalam melaksanakan pekerjaannya dengan teratur, tertib dan lancar. Disiplin kerja karyawan sangat penting bagi perusahaan dalam rangka mewujudkan 
tujuan instansi, tanpa disiplin kerja karyawan yang baik, sulit bagi suatu instansi mencapai hasil yang optimal.

Disiplin kerja mencerminkan besarnya rasa tanggung jawab seseorang terhadap tugas-tugas yang diberikan kepadanya, hal ini mendorong semangat kerja sehingga dapat terwujudkan tujuan perusahaan. Disiplin kerja merupakan kunci keberhasilan instansi dalam mencapai tujuannya. Disiplin kerja dapat tumbuh dengan adanya motivasi yang diberikan kepada karyawan, sehingga dapat mendorong karyawan bekerja secara maksimal dan produktif guna mencapai tujuan perusahaan. Pada disiplin kerja, karyawan yang tidak disiplin dapat kita ketahui bahwa karyawan tersebut tidak mempunyai rasa tanggung jawab dan taat dengan aturan yang berlaku, karyawan yang kurang disiplin dapat menyebabkan kurangnya efisiensi kerja dan efektivitas pekerjaan serta perusahaan tidak dapat meraih tujuannya, sehingga dapat dikatakan produktivitas karyawan menurun. Karyawan yang memiliki disiplin kerja yang tinggi akan berdampak kepada karyawan itu sendiri dalam merah prestasi dan berdampak kepada perusahaan dalam pencapaian target yang optimal(Agustini \& Dewi, 2019)

Santoni \& Suana (2018) menyatakan bahwa motivasi sangat diperlukan pada diri seseorang sehingga motivasi adalah salah satu kunci untuk mencapai suatu kebutuhan yang ingin dicapai. Motivasi adalah fakta emosional yang berarti kebutuhan dan keinginan harus ditangani dengan menyusun rencana insentif (Maduka, 2014). Motivasi adalah faktor utama yang mempengaruhi sumber daya manusia organisasi (Ramzan \& Ali, 2014). Dengan kata lain, timbulnya motivasi pada diri seseorang karena adanya harapan, sasaran, kebutuhan, dorongan, keinginan, serta tujuan (My, 2017). Dorongan bekerja akan timbul pada diri seseorang disebabkan oleh adanya kebutuhan yang harus dipenuhi dan adanya tingkat kebutuhan yang berbeda pada setiap pegawai, sehingga menimbulkan perbedaan motivasi dalam berprestasi, dengan adanya motivasi yang diberikan oleh perusahaan, diharapkan akan memberikan kontribusi penuh oleh karyawan agar bekerja secara produktif (Pawirosumarto \& Muchtar, 2017).

Pada penelitian ini kurangnya motivasi yang diberikan oleh pihak manajemen kepada karyawan menyebabkan menurunnya produktivitas karyawan, melalui observasi yang dilakukan di Jimbaran Bay Seafood Café, dimana permasalahan dalam motivasi yaitu kurangnya pemberian motivasi oleh manajemen terhadap karyawan untuk bekerja lebih baik dan kurangnya karyawan yang termotivasi untuk menghadapi tantangan dan memecahkan masalah untuk dapat bekerja dengan baik.

Berdasarkan latar belakang, maka dapat dirumuskan pokok masalah sebagai berikut: 1) Apakah kompensasi berpengaruh signifikan terhadap produktivitas karyawan di perusahaan Jimbaran Bay Seafood Café ? 2) Apakah disiplin kerja berpengaruh signifikan terhadap produktivitas karyawan di perusahaan Jimbaran Bay Seafood Café ? 3) Apakah motivasi kerja berpengaruh signifikan terhadap produktivitas karyawan di perusahaan Jimbaran Bay Seafood Café ?

Penelitian ini dapat memberikan masukan - masukan mengenai Peranan Kompensasi, Disiplin Kerja dan Motivasi Kerja Dalam Upaya Meningkatkan Produktivitas Kerja Karyawan, sehingga menjadi pertimbangan dalam 
melaksanakannya. Hasil dari penelitian ini dapat dijadikan sebagai informasi dan bahan pertimbangan bagi perusahaan Jimbaran Bay Seafood Café dalam menangani produktivitas karyawan, dan memberikan masukan tentang betapa pentingnya kompensasi, disiplin kerja dan motivasi kerja terhadap produktivitas karyawan untuk mencapai tujuan perusahaan.

Teori yang digunakan dalam penelitian ini adalah teori harapan. Teori harapan adalah kekuatan dari suatu kecenderungan untuk bertindak dalam cara tertentu bergantung pada kekuatan dari suatu harapan bahwa tindakan tersebut akan diikuti dengan hasil yang ada (Elingit et al., 2019). Teori ini akan digunakan untuk menjelaskan model dalam pendekatan ini. Teori harapan atau Teori Ekspektansi (Expectancy Theory of motivation) dikemukakan oleh Vroom menekankan pada faktor hasil (Abdel-kader \& Luther, 1018), ada tiga asumsi dari teorinya adalah sebagai berikut: 1) Setiap individu percaya bahwa bila mereka berperilaku dengan cara tertentu, maka individu tersebut akan memperoleh hal tertentu. Ini disebut sebuah harapan hasil (outcome expentancy) sebagai penilaian subjektif seseorang atas kemungkinan bahwa suatu hasil tertentu akan muncul dari tindakan orang tersebut. 2) Setiap hasil mempunyai nilai, atau daya tarik bagi orang tertentu. Ini disebut valensi (valence) sebagai nilai yang orang berikan kepada suatu hasil yang diharapkan. 3) Teori ini menyatakan bahwa kekuatan yang memotivasi seseorang untuk bekerja giat dalam mengerjakan pekerjaannya tergantung dari hubungan timbal balik antara apa yang diinginkan dan dibutuhkan dari hasil pekerjaan itu (Rahardjo, 2017).

Teori berikutnya adalah Teori Motivasi Abraham Maslow "A theory of human motivation". Teori ini berarti seorang berperilaku/bekerja, karena adanya dorongan untuk memenuhi bermacam-macam kebutuhannya. Maslow berpendapat kebutuhan yang diinginkan seseorang berjenjang, artinya bila kebutuhan yang pertama telah terpenuhi, maka kebutuhan tingkat kedua akan menjadi yang utama dan seterusnya sampai tingkat kebutuhan kelima. Teori motivasi yang dikembangkan Maslow menyatakan bahwa setiap diri manusia itu terdiri dari atas lima tingkatan atau hierarki kebutuhan, yaitu: 1) Kebutuhan Fisiologis (Physiological Needs) seperti : kebutuhan makan minum, perlindungan fisik, bernafas, seksual, dsb. Ini merupakan kebutuhan yang paling dasar atau kebutuhan tingkat rendah. 2) Kebutuhan Rasa Aman (Safety Needs) yaitu kebutuhan akan perlindungan dari ancaman, bahaya, pertentangan dan lingkungan hidup, tidak dalam arti fisik semata, melainkan mental, psikologikal dan intelektual. 3) Kebutuhan Sosial (Social Needs) berarti kebutuhan untuk merasa memiliki yaitu kebutuhan untuk diterima dalam kelompok, berafiliasi, berinteraksi dan kebutuhan untuk mencintai serta dicintai. 4) Kebutuhan Pengakuan (Esteem Needs) yaitu kebutuhan untuk dihormati dan dihargai oleh orang lain. 5) Kebutuhan Aktualisasi Diri (Self-Actualization Needs) yaitu kebutuhan untuk menggunakan kemampuan, skill, potensi, kebutuhan untuk berpendapat, dengan mengemukakan ide-ide dan memberi kritik terhadap sesuatu. Jadi menurut Maslow jika ingin memotivasi seseorang, perlu memahami sedang berada pada anak tangga manakah orang itu dan memfokuskan pada pemenuhan kebutuhan-kebutuhnannya atau kebutuhan diatas tingkat itu. 
Putra \& Suana (2018) menyatakan bahwa kompensasi berpengaruh positif dan signifikan terhadap produktivitas karyawan pada Maya Ubud Resort \& Spa. Purwanto \& Wulandari (2016) menyatakan bahwa Kompensasi berpengaruh positif dan signifikan terhadap Produktivitas Kerja Karyawan pada PT.Pelangi. Agustini \& Dewi (2019) memperkuat penelitian dengan penelitian yang telah dilakukan yang menyatakan bahwa kompensasi berpengaruh positif dan signifikan terhadap produktivitas karyawan pada Single Fin Restaurant \& Bar Bali. Abdussamad (2014) juga memperkuat penelitian dengan penelitian yang telah dilakukan yang menyatakan bahwa kompensasi berpengaruh positif dan signifikan terhadap produktivitas karyawan pada PT. Sinar Galesong Pratama.

Santoni \& Suana (2018) mempertegas dalam penelitian yang telah dilakukan bahwa berdasarkan hasil analisis pengaruh kompensasi terhadap produktivitas kerja diperoleh pengaruh positif signifikan antara kompensasi terhadap produktivitas kerja yang berarti apabila kompensasi yang diberikan perusahaan baik maka produktivitas karyawan di Honda Denpasar Agung akan meningkat dan sebaliknya jika kompensasi yang diberikan perusahaan buruk maka produktivitas kerja karyawan di Honda Denpasar Agung akan menurun. Berdasarkan hasil penelitian sebelumnya maka dapat dirumuskan hipotesis penelitian sebagai berikut:

$\mathrm{H}_{1}$ : Kompensasi berpengaruh positif terhadap Produktivitas Karyawan

Agustini \& Dewi (2019) menyatakan bahwa disiplin kerja berpengaruh positif dan signifikan terhadap produktivitas karyawan pada Single Fin Restaurant\&Bar Bali. Ruauw dkk. (2015) menyatakan bahwa disiplin kerja bepengaruh positif dan signifikan terhadap produktivitas pegawai pada Village Tingkulu Wanea districts of Manado. Abdussamad (2014) juga memperkuat penelitian dengan penelitian yang telah dilakukan yang menyatakan bahwa disiplin kerja berpengaruh positif dan signifikan terhadap produktivitas karyawan pada PT. Sinar Galesong Pratama. Ananta \& Adnyani (2016)mempertegas dalam penelitian yang telah dilakukan Variabel disiplin kerja berpengaruh positif dan signifnikan terhadap produktivitas kerja karyawan pada Villa Mahapala Sanur. Berdasarkan hasil penelitian sebelumnya maka dapat dirumuskan hipotesis penelitian sebagai berikut:

$\mathrm{H}_{2}$ : Disiplin Kerja berpengaruh positif terhadap Produktivitas Karyawan

Dewi \& Sudibya (2018) motivasi berpengaruh positif dan signifikan terhadap produktivitas karyawan di Hotel Natya Kuta. Putra \& Ardana (2016) menyatakan bahwa motivasi secara langsung berpengaruh positif dan signifikan terhadap kepuasan kerja perajin perak. Sudiardhita et al. (2018) memperkuat penelitian dengan penelitian yang telah dilakukan yang menyatakan bahwa motivasi berpengaruh positif dan signifikan terhadap produktivitas karyawan di PT. Artha Prima Finance Denpasar. Bawoleh \& Tielung (2015) juga memperkuat penelitian dengan penelitian yang telah dilakukan yang menyatakan bahwa motivasi berpengaruh positif dan signifikan terhadap produktivitas karyawan di PR Fajar Berlian Tulungagung. Agustini \& Dewi (2019) mempertegas dalam penelitian yang telah dilakukan bahwa motivasi berpengaruh positif dan signifikan terhadap produktivitas karyawan di Single Fin Restaurant\&Bar Bali. 
Berdasarkan hasil penelitian sebelumnya maka dapat dirumuskan hipotesis penelitian sebagai berikut:

$\mathrm{H}_{3}$ : Motivasi Kerja berpengaruh positif terhadap Produktivitas Karyawan

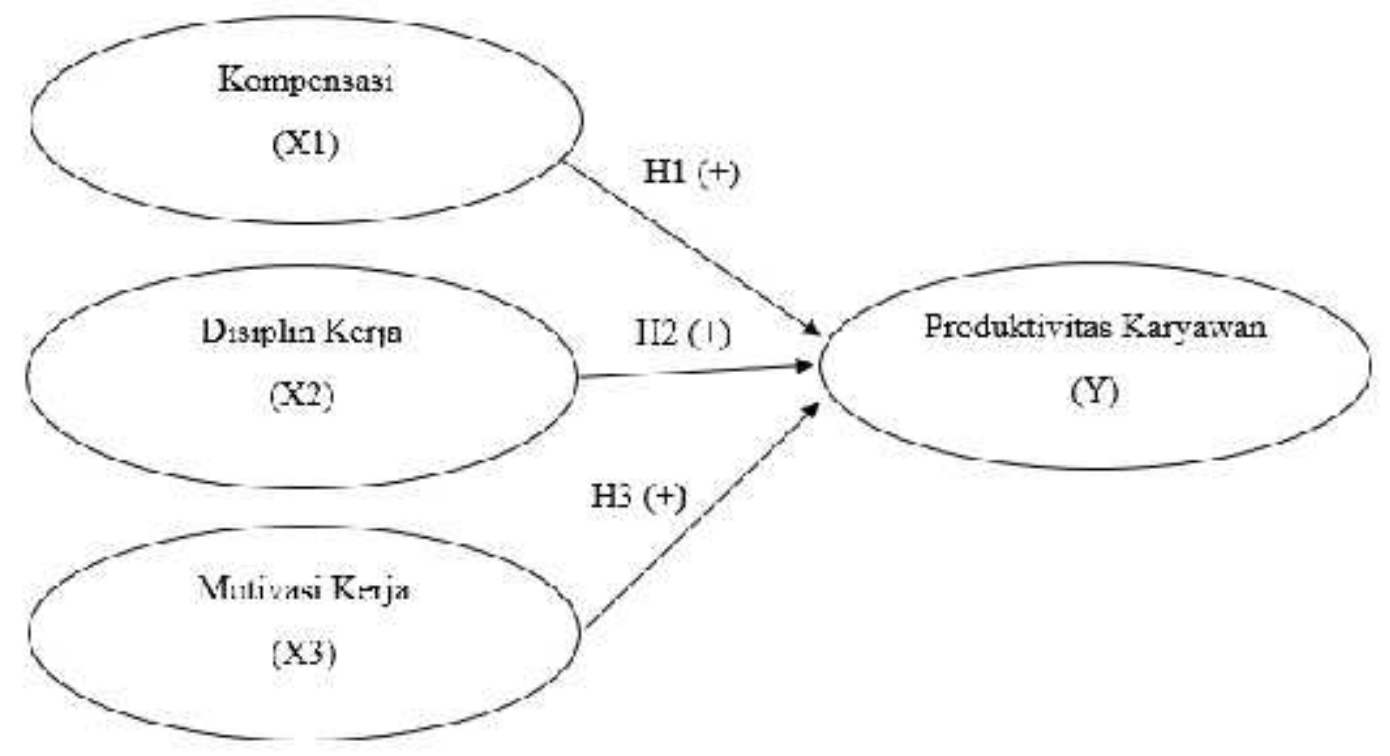

Gambar 1. Kerangka Konseptual

\section{METODE PENELITIAN}

Dalam penelitian ini dilakukan sebuah pendekatan yang berbentuk asosiatif. Metode penelitian menggunakan metode kuantitatif Penelitian ini dilakukan di Jimbaran Bay Seafood Cafe yang terletak di Pantai Kedonganan Kuta - Bali. Lokasi ini dipilih karena ditemukan masalah-masalah terkait produktivitas karyawan, dimana diduga tingkat produktivitas karyawan dipengaruhi oleh kompensasi, disiplin kerja dan motivasi kerja. Objek pada penelitian ini adalah kompensasi $\left(\mathrm{X}_{1}\right)$, disiplin kerja $\left(\mathrm{X}_{2}\right)$ dan motivasi kerja $\left(\mathrm{X}_{3}\right)$ terhadap produktivitas karyawan $(\mathrm{Y})$. Variabel terikat dalam penelitian ini adalah produktivitas karyawan $(\mathrm{Y})$. Variabel bebas dalam penelitian ini adalah kompensasi $\left(\mathrm{X}_{1}\right)$, disiplin kerja $\left(\mathrm{X}_{2}\right)$ dan motivasi kerja $\left(\mathrm{X}_{3}\right)$

Populasi dalam penelitian ini adalah semua karyawan Jimbaran Bay Seafood Cafe. Responden yang digunakan dalam penelitian ini yaitu jumlah populasi sebesar 55 responden yang merupakan seluruh karyawan Jimbaran Bay Seafood Cafe. Status dari seluruh karyawan yaitu sebagai karyawan tetap. Metode penentuan sampel yang digunakan dalam penelitian adalah metode sampel jenuh. Untuk memperoleh data, penelitian ini menggunakan teknik pengumpulan data dengan menggunakan beberapa metode seperti wawancara dan kuesioner.

Data kualitatif dalam penelitian ini adalah pernyataan kuisioner penelitian dan gambaran umum mengenai Jimbaran Bay Seafood Cafe. Dalam penelitian ini data kuantitatif yang dimaksud adalah jumlah karyawan serta jumlah skor jawaban kuisioner yang telah dikuantifikasi dengan pembobotan jawaban 
responden yang terdiri dari data kompensasi, disiplin kerja motivasi dan produktivitas karyawan Jimbaran Bay Seafood Café. Sumber primer yang digunakan dalam penelitian ini berupa kuesioner yang dibagikan ke responden yang merupakan karyawan Jimbaran Bay Seafood Café. Sumber sekunder yang digunakan dalam penelitian ini adalah dokumen laporan yang telah dibuat oleh pihak perusahaan Jimbaran Bay Seafood Café. Definisi operasional merupakan suatu definisi variabel yang telah dipilih oleh peneliti. Definisi operasional didalam penelitian ini adalah kompensasi, disiplin kerja, motivasi kerja dan produktivitas karyawan

Produktivitas kerja merupakan kemampuan karyawan dalam menyelesaikan suatu pekerjaan dengan efektif dan efesien yang telah ditetapkan oleh perusahaan untuk mencapai tujuan dari perusahaan. Indikator produktivitas karyawan adalah sebagai berikut: Kualitas kerja $\left(\mathrm{Y}_{1}\right)$ merupakan hasil yang dicapai karyawan dalam menyelesaikan pekerjaan sesuai dengan standar yang berlaku di perusahaan Indikator ini diukur dari persepsi responden mengenai standar mutu yang tinggi dalam menyelesaikan pekerjaan dan hasil dari pekerjaan selalu berkualitas. Kuantitas Kerja $\left(\mathrm{Y}_{2}\right)$ merupakan ukuran yang dicapai karyawan dalam memenuhi standar perusahaan dalam bentuk jumlah yang dihasilkan. Indikator ini diukur dari persepsi responden mengenai mengerjakan sebagaian besar total pekerjaan tiap harinya dan selalu mencapai target yang diberikan dalam tim. Waktu dan kecepatan karyawan untuk menyelesaikan pekerjaanya ( $\left.\mathrm{Y}_{3}\right)$ merupakan jumlah waktu karyawan dalam menyelesaikan tugas yang dibebankan. Indikator ini diukur dari persepsi responden mengenai menyelesaikan tugas dengan cepat.

Kompensasi merupakan pendapatan yang diterima oleh karyawan dalam bentuk uang, insentif dan tunjangan yang diperoleh dari hasil balas jasa perusahaan untuk karyawan yang telah menyelesaikan suatu pekerjaan dari perusahaan. Indikator kompensasi yaitu sebagai berikut: Gaji $\left(\mathrm{X}_{1.1}\right)$, indikator ini dapat diukur melalui gaji diberikan tepat waktu, mendapat kenaikan gaji setiap tahun, gaji dapat memenuhi kebutuhan hidup, gaji sesuai dengan pekerjaan dan merasa puas dengan gaji yang diterima. Insentif $\left(\mathrm{X}_{1.2}\right)$, indikator ini dapat diukur melalui mendapat bonus berupa uang lembur bila bekerja diluar jam kerja; Tunjangan $\left(\mathrm{X}_{1.3}\right)$, indikator ini dapat diukur melalui mendapat fasilitas kesehatan untuk keluarga, tunjangan hari raya (THR) setiap tahun, tunjangan berupa dana pensiun dan puas dengan tunjangan yang diberikan.

Disiplin kerja merupakan suatu tindakan atau suatu sikap dalam mentaati ketentuan dan standar yang harus dipenuhi. Indikator disiplin kerja sebagai berikut: Ketepatan waktu kerja $\left(\mathrm{X}_{2.1}\right)$ indikator ini dapat diukur melalui datang lebih awal di tempat kerja, pulang kerja sesuai dengan jam yang telah ditentukan, makan siang saat jam istirahat dan kembali ketempat kerja sebelum jam istirahat berakhir. Kerapian berpakaian $\left(\mathrm{X}_{2.2}\right)$ indikator ini dapat diukur melalui kerapian seragam saat jam kerja selalu diperhatikan. Kepatuhan pada aturan perusahaan $\left(\mathrm{X}_{2.3}\right)$ indikator ini dapat diukur melalui hadir setiap hari ditempat kerja, memberikan surat keterangan dokter saat tidak masuk kerja karena sakit dan memakai seragam sesuai dengan hari yang titetapkan. Tanggung 
jawab (X2.4) indikator ini dapat diukur melalui tugas dikerjakan dengan tanggung jawab dan bertanggung jawab atas kesalahan yang telah dilakukan.

Motivasi adalah suatu faktor yang dapat mendorong karyawan jimbaran bay seafood café dalam meningkatkan kinerja didalam perusahaan, motivasi juga merupakan suatu kondisi untuk membangkitkan dan mengarahkan suatu karyawan untuk bekerja lebih baik lagi guna mencapai tujuan dari sebuah perusahaan. Indikator motivasi yakni: Perilaku Karyawan $\left(\mathrm{X}_{3.1}\right)$ Kemampuan karyawan memilih perilaku bekerja yang akan mereka pilih. Perilaku karyawan yang baik dalam bekerja menunjukkan bahwa karyawan termotivasi dalam bekerja. Usaha Karyawan $\left(\mathrm{X}_{3.2}\right)$ Hal ini berkaitan dengan usaha keras yang dilakukan karyawan dalam bekerja. Usaha keras yang dilakukan karyawan menandakan bahwa karyawan termotivasi dalam bekerja. Kegigihan Karyawan $\left(\mathrm{X}_{3.3}\right)$ Kegigihan karyawan mengacu pada perilaku seseorang yang tetap ingin bekerja walaupun adanya rintangan, masalah, dan halangan. Kegigihan karyawan yang tinggi menunjukkan bahwa karyawan memiliki motivasi yang tinggi.

\section{HASIL DAN PEMBAHASAN}

Jimbaran Bay Seafood Café merupakan usaha yang bergerak dibidang kuliner dengan bahan pokok utama yaitu seafood yang kemudian dibakar dan diolah sedemikian rupa agar menarik para konsumen. Jimbaran Bay Seafood Café merupakan salah satu program desa adat kedonganan yang dikembangkan dipesisir pantai. Desa adat kedonganan merupakan desa yang memiliki mata pencarian sebagai nelayan, oleh karena itu dikembangkan cafe dengan bahan pokok seafood. Jimbaran Bay Seafood Café ini beralokasikan di Pantai Kedonganan Kuta - Bali yang memiliki panorama indah. Jimbaran Bay Seafood Café ini dikelola oleh pemilik saham terbesar yaitu bapak ketut suastana yang direkomendasikan oleh krama banjar. Berdasarkan hasil penelitian yang dilakukan terhadap karyawan Di Jimbaran Bay Seafood Cafe dapat diketahui karakteristik respondennya meliputi jenis kelamin, usia dan pendidikan terakhir yang dijelaskan pada Tabel 1.

Tabel 1.

Karakteristik Responden Di Jimbaran Bay Seafood Cafe

\begin{tabular}{lllll}
\hline No & Variabel & Klasifikasi & $\begin{array}{l}\text { Jumlah } \\
\text { (orang) }\end{array}$ & $\begin{array}{l}\text { Persentase } \\
(\mathbf{\%})\end{array}$ \\
\hline \multirow{3}{*}{1} & Jenis & Laki - Laki & 34 & 61.82 \\
& Kelamin & Perempuan & 21 & 38.18 \\
& Jumlah & & 55 & 100 \\
& & 18-24 Tahun & 20 & 36.36 \\
2 & Usia & 25-34 Tahun & 24 & 43.64 \\
& & 35-40 Tahun & 10 & 18.18 \\
& Jumlah & & 1 & 1.82 \\
3 & Pendidikan & SMA & 55 & 100 \\
& terakhir & Diploma & 10 & 18.18 \\
& Jumlah & & 28 & 50.91 \\
& & & 17 & 30.91 \\
\hline
\end{tabular}

Sumber : Data diolah, 2019 
Berdasarkan Tabel 1. menunjukkan jumlah karyawan Di Jimbaran Bay Seafood Cafe yang di jadikan sampel sebanyak 55 orang. Jika di lihat dari jenis kelamin, jenis kelamin laki-laki mendominasi dalam penelitian ini dengan persentase sebesar 61,82 persen. Jika di lihat dari usia, yang memiliki usia 25-34 tahun mendominasi dengan presentase sebesar 43,64 persen. Jika di lihat dari tingkat pendidikan yang memiliki tingkat pendiddikan terakhir Diploma yang mendominasi dengan persentase sebesar 50,91 persen.

Tabel 2.

Hasil Uji Validitas

\begin{tabular}{|c|c|c|c|c|}
\hline No & Variabel & $\begin{array}{l}\text { Item } \\
\text { Pernyataan }\end{array}$ & $\begin{array}{l}\text { Korelasi } \\
\text { Total }\end{array}$ & Keterangan \\
\hline \multirow{6}{*}{1} & \multirow{6}{*}{ Kompensasi } & $\mathrm{X} 1.1$ & 0,732 & Valid \\
\hline & & $\mathrm{X} 1.2$ & 0,936 & Valid \\
\hline & & X1.3 & 0,935 & Valid \\
\hline & & X1.4 & 0,849 & Valid \\
\hline & & $\mathrm{X} 1.5$ & 0,938 & Valid \\
\hline & & X1.6 & 0,937 & Valid \\
\hline \multirow{4}{*}{2} & \multirow{5}{*}{ Disiplin kerja } & $\mathrm{X} 2.1$ & 0,971 & Valid \\
\hline & & $\mathrm{X} 2.2$ & 0,955 & Valid \\
\hline & & $\mathrm{X} 2.3$ & 0,946 & Valid \\
\hline & & X2.4 & 0,889 & Valid \\
\hline & & X3.1 & 0,895 & Valid \\
\hline \multirow{6}{*}{3} & \multirow{6}{*}{ Motivasi kerja } & X3.2 & 0,939 & Valid \\
\hline & & X3.3 & 0,928 & Valid \\
\hline & & X3.4 & 0,884 & Valid \\
\hline & & X3.5 & 0,936 & Valid \\
\hline & & X3.6 & 0,917 & Valid \\
\hline & & X3.7 & 0,847 & Valid \\
\hline \multirow{6}{*}{4} & \multirow{6}{*}{ Produktivitas karyawan } & X3.8 & 0,620 & Valid \\
\hline & & Y1.1 & 0,937 & Valid \\
\hline & & Y1.2 & 0,947 & Valid \\
\hline & & Y1.3 & 0,909 & Valid \\
\hline & & Y1.4 & 0,863 & Valid \\
\hline & & Y1.5 & 0,914 & Valid \\
\hline
\end{tabular}

Sumber : Data diolah, 2019

Tabel 2. menunjukkan bahwa seluruh koefisien korelasi dari indikator variabel yang diuji nilainya lebih besar dari 0,30 ( $\mathrm{r}>0,3)$. Hasil tersebut menunjukkan bahwa seluruh indikator yang terdapat pada penelitian ini terbukti valid.

Tabel 3.

Hasil Uji Reliabilitas

\begin{tabular}{lll}
\hline Variabel & Cronbach's Alpha & Keterangan \\
\hline Kompensasi $\left(\mathrm{X}_{1}\right)$ & 0,947 & Reliabel \\
Disiplin kerja $\left(\mathrm{X}_{2}\right)$ & 0,953 & Reliabel \\
Motivasi kerja $\left(\mathrm{X}_{3}\right)$ & 0,955 & Reliabel \\
Produktivitas karyawan $(\mathrm{Y})$ & 0,950 & Reliabel \\
\hline
\end{tabular}

Sumber : Data diolah, 2019 
Tabel 3. menunjukkan masing-masing nilai Cronbach's Alpha pada tiap instrumen tersebut lebih besar dari 0,6 (Cronbach's Alpha > 0,6). Hal tersebut menunjukkan bahwa semua instrumen reliabel sehingga dapat digunakan untuk melakukan penelitian.

Tabel 4.

Deskripsi Jawaban Responden terhadap Produktivitas Karyawan

\begin{tabular}{|c|c|c|c|c|c|c|c|c|c|}
\hline \multirow[t]{2}{*}{ No } & \multirow[t]{2}{*}{ Pernyataan } & \multicolumn{3}{|c|}{$\begin{array}{l}\text { Proporsi } \\
\text { Responden } \\
\text { (orang) }\end{array}$} & \multicolumn{2}{|c|}{ Jawaban } & \multirow[t]{2}{*}{ Jumlah } & \multirow[t]{2}{*}{$\begin{array}{l}\text { Rata- } \\
\text { Rata }\end{array}$} & \multirow[t]{2}{*}{ Kriteria } \\
\hline & & 1 & 2 & 3 & 4 & 5 & & & \\
\hline 1 & \begin{tabular}{lr}
\multicolumn{3}{l}{ Saya memiliki standar yang } \\
tinggi di dalam \\
menyelesaikan & pekerjaan \\
$\left(\mathrm{Y}_{1.1 .1}\right)$ &
\end{tabular} & 4 & 11 & 8 & 25 & 7 & 185 & 3.36 & Sedang \\
\hline 2 & $\begin{array}{l}\text { Hasil dari pekerjaan saya } \\
\text { selalu berkualitas }\left(\mathrm{Y}_{1.1 .2}\right)\end{array}$ & 5 & 10 & 6 & 28 & 6 & 185 & 3.36 & Sedang \\
\hline 3 & $\begin{array}{l}\text { Saya telah mengerjakan } \\
\text { sebagian besar dari total } \\
\text { pekerjaan setiap harinya } \\
\left(\mathrm{Y}_{1.2 .1}\right)\end{array}$ & 0 & 15 & 10 & 22 & 8 & 188 & 3.42 & Tinggi \\
\hline 4 & $\begin{array}{l}\text { Saya selalu mencapai target } \\
\text { yang diberikan dalam tim } \\
\left(\mathrm{Y}_{1.2 .2}\right)\end{array}$ & 3 & 13 & 10 & 17 & 12 & 187 & 3.40 & Sedang \\
\hline 5 & $\begin{array}{l}\text { Saya telah menyelesaikan } \\
\text { tugas dengan efisien }\left(\mathrm{Y}_{1.3 .1}\right)\end{array}$ & 0 & 16 & 5 & 25 & 9 & 192 & 3.49 & Tinggi \\
\hline \multicolumn{2}{|c|}{ Rata-rata } & & & & & & & 3,41 & Tinggi \\
\hline
\end{tabular}

Tabel 5.

Deskripsi Jawaban Responden terhadap Kompensasi

\begin{tabular}{|c|c|c|c|c|c|c|c|c|c|}
\hline \multirow[t]{2}{*}{ No } & \multirow[t]{2}{*}{ Pernyataan } & \multicolumn{3}{|c|}{$\begin{array}{l}\text { Proporsi } \\
\text { Responden } \\
\text { (orang) }\end{array}$} & \multirow{2}{*}{\multicolumn{2}{|c|}{ Jawaban }} & \multirow[t]{2}{*}{ Jumlah } & \multirow[t]{2}{*}{$\begin{array}{l}\text { Rata- } \\
\text { Rata }\end{array}$} & \multirow[t]{2}{*}{ Kriteria } \\
\hline & & 1 & 2 & 3 & & 5 & & & \\
\hline 1 & $\begin{array}{l}\text { Saya menerima gaji setiap } \\
\text { bulan }\left(\mathrm{X}_{1.1 .1}\right)\end{array}$ & 0 & 11 & 13 & 25 & 6 & 191 & 3.47 & Tinggi \\
\hline 2 & $\begin{array}{l}\text { Upah yang saya terima sesuai } \\
\text { dengan pekerjaan }\left(\mathrm{X}_{1.1 .2}\right) \\
\text { Saya mendapatkan insentif }\end{array}$ & 5 & 11 & 6 & 30 & 3 & 180 & 3.27 & Sedang \\
\hline 3 & $\begin{array}{l}\text { karena telah menyelesaikan } \\
\text { pekerjaan sesuai target }\left(X_{1.2 .1}\right)\end{array}$ & 5 & 8 & 15 & 19 & 8 & 182 & 3.31 & Sedang \\
\hline 4 & $\begin{array}{l}\text { Saya mendapatkan fasilitas } \\
\text { yang baik saat bekerja }\left(\mathrm{X}_{1.2 .2}\right)\end{array}$ & 2 & 7 & 11 & 33 & 2 & 191 & 3.47 & Tinggi \\
\hline 5 & $\begin{array}{l}\text { Tunjangan yang saya terima } \\
\text { sudah cukup baik }\left(\mathrm{X}_{1.3 .1}\right)\end{array}$ & 5 & 11 & 7 & 29 & 3 & 179 & 3.25 & Sedang \\
\hline 6 & $\begin{array}{lll}\text { Jaminan } & \text { kesehatan } & \text { yang } \\
\text { diberikan perusahaan telah } & \text { sesuai dengan kebutuhan } \\
\left(\mathrm{X}_{1.3 .2}\right) & & \end{array}$ & 5 & 8 & 16 & 18 & 8 & 181 & 3.29 & Sedang \\
\hline Rat & -rata & & & & & & & 3,35 & Sedang \\
\hline
\end{tabular}


Tabel 4. menunjukan persepsi responden mengenai variabel produktivitas karyawan dikategorikan tinggi. Jika dilihat secara menyeluruh yaitu 3 indikator berada dibawah rata-rata variabel dan 2 indikator berada diatas rata-rata variabel. Adapun indikator yang berada diatas rata-rata yaitu indikator $Y_{1.2 .1}$ sebesar 3,42 dan indikator $Y_{1.3 .1}$ sebesar 3,49. Selain itu terdapat 3 indikator berada dibawah ratarata, yaitu indikator $Y_{1.1 .1}$ sebesar 3,36 indikator $Y_{1.1 .2}$ sebesar 3,36 dan indikator Y1.2.2 sebesar 3.40.

Tabel 5. menunjukan persepsi responden mengenai variabel kompensasi dikategorikan tinggi. Jika dilihat secara menyeluruh yaitu 4 indikator berada dibawah rata-rata variabel dan 2 indikator berada diatas rata-rata variabel. Adapun indikator yang berada diatas rata-rata yaitu indikator $\mathrm{X}_{1.1 .1}$ sebesar 3,47 dan indikator $\mathrm{X}_{1.2 .2}$ sebesar 3,47. Selain itu terdapat 4 indikator berada dibawah ratarata, yaitu indikator $X_{1.1 .2}$ sebesar 3,27 indikator $X_{1,2,1}$ sebesar 3,31 indikator $X_{1.3 .1}$ sebesar 3,25 dan indikator $\mathrm{X}_{1.3 .2}$ sebesar 3,29.

Tabel 6.

Deskripsi Jawaban Responden terhadap disiplin kerja

\begin{tabular}{|c|c|c|c|c|c|c|c|c|c|}
\hline \multirow[t]{2}{*}{ No } & \multirow[t]{2}{*}{ Pernyataan } & \multicolumn{3}{|c|}{$\begin{array}{l}\text { Proporsi } \\
\text { Responden } \\
\text { (orang) }\end{array}$} & \multicolumn{2}{|c|}{ Jawaban } & \multirow[t]{2}{*}{ Jumlah } & \multirow[t]{2}{*}{$\begin{array}{l}\text { Rata- } \\
\text { Rata }\end{array}$} & \multirow[t]{2}{*}{ Kriteria } \\
\hline & & 1 & 2 & 3 & 4 & 5 & & & \\
\hline 1 & $\begin{array}{lrr}\text { Saya tidak } & \text { pernah } \\
\text { terlambat } & \text { masuk } & \text { kerja } \\
\left(\mathrm{X}_{2.1 .1}\right) & & \end{array}$ & 3 & 10 & 8 & 31 & 3 & 186 & 3.38 & Sedang \\
\hline 2 & $\begin{array}{l}\text { Saya menaati peraturan } \\
\text { yang berlaku } \\
\text { bekerja }\left(X_{2.2 .1}\right)\end{array}$ & 3 & 11 & 10 & 28 & 3 & 182 & 3.31 & Sedang \\
\hline 3 & $\begin{array}{l}\text { Perintah yang diberikan } \\
\text { oleh atasan langsung } \\
\text { dikerjakan }\left(\mathrm{X}_{2.3 .1}\right)\end{array}$ & 4 & 9 & 9 & 26 & 7 & 188 & 3.42 & Tinggi \\
\hline 4 & $\begin{array}{l}\text { Saya menyelesaikan } \\
\text { pekerjaan dengan penuh } \\
\text { tanggung jawab }\left(\mathrm{X}_{2.4 .1}\right)\end{array}$ & 6 & 9 & 17 & 15 & 8 & 175 & 3.18 & Sedang \\
\hline \multicolumn{2}{|c|}{ Rata-rata } & & & & & & & 3,32 & Sedang \\
\hline
\end{tabular}

Sumber : Data diolah, 2019

Tabel 6. menunjukan persepsi responden mengenai variabel disiplin kerja dikategorikan tinggi. Jika dilihat secara menyeluruh yaitu 2 indikator berada dibawah rata-rata variabel dan 2 indikator berada diatas rata-rata variabel. Adapun indikator yang berada diatas rata-rata yaitu indikator $X_{2.1 .1}$ sebesar 3,38 dan indikator $\mathrm{X}_{2.3 .1}$ sebesar 3,42. Selain itu terdapat 2 indikator berada dibawah ratarata, yaitu indikator $\mathrm{X}_{2.2 .1}$ sebesar 3,31 dan indikator $\mathrm{X}_{2.4 .1}$ sebesar 3,18.

Tabel 7. menunjukan persepsi responden mengenai variabel motivasi kerja dikategorikan tinggi. Jika dilihat secara menyeluruh yaitu 4 indikator berada dibawah rata-rata variabel dan 4 indikator berada diatas rata-rata variabel. Adapun indikator yang berada diatas rata-rata yaitu indikator $\mathrm{X}_{3.1 .1}$ sebesar 3,40 indikator $X_{3.1 .2}$ sebesar 3,38 indikator $X_{3.2 .2}$ sebesar 3,40 dan indikator $X_{3.2 .3}$ sebesar 3,35. 
Selain itu terdapat 4 indikator berada dibawah rata-rata, yaitu indikator $\mathrm{X}_{3.2 .1}$ sebesar 3,29 indikator $X_{3.2 .4}$ sebesar 3,27 indikator $X_{3.3 .1}$ sebesar 3,11 dan indikator $\mathrm{X}_{3.3 .2}$ sebesar 2,75.

Tabel 7.

Deskripsi Jawaban Responden terhadap motivasi kerja

\begin{tabular}{|c|c|c|c|c|c|c|c|c|c|}
\hline \multirow[t]{2}{*}{ No } & \multirow[t]{2}{*}{ Pernyataan } & \multicolumn{3}{|c|}{$\begin{array}{l}\text { Proporsi } \\
\text { Responden } \\
\text { (orang) }\end{array}$} & \multicolumn{2}{|c|}{ Jawaban } & \multirow[t]{2}{*}{ Jumlah } & \multirow[t]{2}{*}{$\begin{array}{l}\text { Rata- } \\
\text { Rata }\end{array}$} & \multirow[t]{2}{*}{ Kriteria } \\
\hline & & 1 & 2 & 3 & 4 & 5 & & & \\
\hline 1 & $\begin{array}{llr}\text { Saya memiliki } & \text { rasa } \\
\text { bertanggung jawab } & \text { yang } \\
\text { tinggi atas pekerjaan } & \text { saya } \\
\left(\mathrm{X}_{3.1 .1}\right) & \end{array}$ & 1 & 16 & 7 & 22 & 9 & 187 & 3.40 & Sedang \\
\hline 2 & $\begin{array}{l}\text { Saya senang mendapatkan } \\
\text { pujian atas apa yang saya } \\
\text { kerjakan }\left(\mathrm{X}_{3.1 .2}\right)\end{array}$ & 2 & 13 & 8 & 26 & 6 & 186 & 3.38 & Sedang \\
\hline 3 & $\begin{array}{l}\text { Saya menginginkan upah } \\
\text { yang sesuai dengan apa yang } \\
\text { saya kerjakan }\left(\mathrm{X}_{3.2 .1}\right)\end{array}$ & 4 & 12 & 9 & 24 & 6 & 181 & 3.29 & Sedang \\
\hline 4 & $\begin{array}{l}\text { Saya ingin mendapatkan } \\
\text { prestasi di dalam bekerja } \\
\left(\mathrm{X}_{3.2 .2}\right)\end{array}$ & 0 & 17 & 7 & 23 & 8 & 187 & 3.40 & Sedang \\
\hline 5 & $\begin{array}{l}\text { Saya menginginkan insetif } \\
\text { yang sesuai dengan apa yang } \\
\text { telah saya kerjakan }\left(\mathrm{X}_{3.2 .3}\right)\end{array}$ & 3 & 12 & 7 & 29 & 4 & 184 & 3.35 & Sedang \\
\hline 6 & $\begin{array}{l}\text { Saya berusaha untuk } \\
\text { memenuhi kebutuhan hidup } \\
\text { saya dengan bekerja }\left(\mathrm{X}_{3.2 .4}\right)\end{array}$ & 3 & 13 & 9 & 26 & 4 & 180 & 3.27 & Sedang \\
\hline 7 & $\begin{array}{l}\text { Saya bekerja dengan harapan } \\
\text { mendapatkan perhatian } \\
\text { orang lain }\left(\mathrm{X}_{3.3 .1}\right)\end{array}$ & 6 & 12 & 15 & 14 & 8 & 171 & 3.11 & Sedang \\
\hline 8 & $\begin{array}{l}\text { Saya berusaha untuk } \\
\text { mengungguli orang lain } \\
\text { dalam bekerja }\left(\mathrm{X}_{3.3 .2}\right)\end{array}$ & 3 & 22 & 16 & 14 & 0 & 151 & 2.75 & Sedang \\
\hline \multicolumn{2}{|c|}{ Rata-rata } & & & & & & & 3,34 & Sedang \\
\hline
\end{tabular}

Tabel 8.

Rangkuman Hasil Analisis Regresi Linear Berganda

\begin{tabular}{llllll}
\hline \multirow{2}{*}{ Model } & \multicolumn{2}{l}{$\begin{array}{l}\text { Unstandardized } \\
\text { Coefficients }\end{array}$} & $\begin{array}{l}\text { Standardized } \\
\text { Coefficients }\end{array}$ & T & Sig. \\
\cline { 2 - 5 } & \multicolumn{1}{l}{ B } & Std. Error & Beta & & \\
\hline (Constant) & 0.147 & 0.306 & & 0.479 & 0.634 \\
Kompensasi & 0.322 & 0.116 & 0.305 & 2.767 & 0.008 \\
Disiplin Kerja & 0.295 & 0.127 & 0.291 & 2.316 & 0.025 \\
Motivasi Kerja & 0.371 & 0.126 & 0.346 & 2.950 & 0.005 \\
\hline Sumber $:$ Data diolah, 2019 & & & &
\end{tabular}

Berdasarkan Tabel 8. dapat ditulis persamaan regresi linear berganda sebagai berikut. 
$Y=0,305 X_{1}+0,291 X_{2}+0,346 X_{3}$

Dimana :

$\mathrm{Y}=$ Produktivitas karyawan

$\mathrm{X}_{1}=$ Kompensasi

$\mathrm{X}_{2}=$ Disiplin kerja

$\mathrm{X}_{3}=$ Motivasi kerja

Persamaan regresi linear berganda tersebut menunjukkan arah masingmasing variabel bebas terhadap variabel terikatnya. Persamaan regresi linear berganda tersebut dapat diuraikan sebagai berikut: $X_{1}$ bernilai 0,305 menunjukkan bahwa kompensasi berpengaruh positif terhadap Produktivitas karyawan di Jimbaran Bay Seafood Cafe, apabila kompensasi meningkat maka Produktivitas karyawan akan mengalami peningkatan dan begitu pula sebaliknya. $\mathrm{X}_{2}$ bernilai 0,291 menunjukkan bahwa Disiplin kerja berpengaruh positif terhadap Produktivitas karyawan di Jimbaran Bay Seafood Cafe, apabila Disiplin kerja karyawan meningkat maka Produktivitas karyawan akan mengalami peningkatan dan begitu pula sebaliknya. $\mathrm{X}_{3}$ bernilai 0,346 menunjukkan bahwa Motivasi kerja berpengaruh positif terhadap Produktivitas karyawan Di Jimbaran Bay Seafood Cafe, apabila Motivasi kerja karyawan meningkat maka Produktivitas karyawan akan mengalami peningkatan dan begitu pula sebaliknya.

Tabel 9.

Uji Normalitas (One-Sample Kolmogorov-Smirnov)

\begin{tabular}{ll}
\hline & $\begin{array}{l}\text { Unstandardized } \\
\text { Residual }\end{array}$ \\
\hline $\mathrm{N}$ & 55 \\
Kolmogorov-Smirnov Z & 1,003 \\
Asymp. Sig. (2-tailed) & 0,267 \\
\hline
\end{tabular}

Sumber : Data diolah, 2019

Berdasarkan uji normalitas dengan menggunakan One-Sample Kolmogorov-Smirnov Test yang ditampilkan pada Tabel 9 tersebut menunjukkan bahwa besarnya nilai Kolmogorov-Smirnov adalah sebesar 0,1335. Nilai Kolmogorov-Smirnov tersebut lebih besar dibandingkan dengan nilai Signifikansi Alpha sebesar 0,05 maka $\mathrm{H}_{\mathrm{o}}$ diterima yang mengindikasikan bahwa data yang digunakan pada penelitian ini terdistribusi normal, sehingga dapat disimpulkan bahwa model memenuhi asumsi normalitas.

Tabel 10.

Uji Multikolinieritas (Tolerance dan Variance Inflation Factor)

\begin{tabular}{lll}
\hline \multirow{2}{*}{ Variabel } & Collinearity Statistics \\
\cline { 2 - 3 } & Tolerance & VIF \\
\hline Kompensasi & 0.474 & 2.109 \\
Disiplin Kerja & 0.365 & 2.740 \\
Motivasi Kerja & 0.418 & 2.391 \\
\hline
\end{tabular}

Sumber : Data diolah, 2019 
Berdasarkan Tabel 10. tersebut ditunjukkan bahwa tidak terdapat variabel bebas yang memiliki nilai tolerance kurang dari 0,10 dan juga tidak ada variabel bebas yang memiliki nilai VIF lebih dari 10. Maka dari pada itu model regresi bebas dari gejala multikoleniaritas.

Tabel 11.

Uji Heteroskedastisitas (Uji Glesjer)

\begin{tabular}{|c|c|c|c|c|c|}
\hline \multirow{2}{*}{ Variabel } & \multicolumn{2}{|c|}{ Unstandardized Coefficients } & \multirow{2}{*}{$\begin{array}{l}\text { Standardized } \\
\text { Coefficients } \\
\text { Beta }\end{array}$} & \multirow[t]{2}{*}{$\mathbf{t}$} & \multirow[t]{2}{*}{ Sig. } \\
\hline & B & Std. Error & & & \\
\hline (Constant) & 0.263 & 0.211 & & 1.245 & 0.219 \\
\hline Kompensasi & 0.048 & 0.080 & 0.120 & 0.595 & 0.554 \\
\hline Disiplin Kerja & 0.046 & 0.088 & 0.119 & 0.520 & 0.605 \\
\hline Motivasi Kerja & -0.053 & 0.087 & -0.131 & -0.610 & 0.544 \\
\hline
\end{tabular}

Sumber : Data diolah, 2019

Berdasarkan Tabel 11. tersebut, ditunjukkan bahwa masing-masing model memiliki nilai signifikansi lebih besar dari 5\%. Hal ini menunjukkan bahwa variabel bebas yang digunakan pada penelitian ini tidak berpengaruh secara signifikan terhadap variabel terikatnya yaitu absolute error, maka dari itu, penelitian ini bebas dari gejala heteroskedastisitas.

Tabel 12.

Analisis Determinasi

\begin{tabular}{llllll}
\hline Model & R & R Square & Adjusted R Square & $\begin{array}{l}\text { Std. Error of the } \\
\text { Estimate }\end{array}$ & \\
\hline 1 & $0.841^{\mathrm{a}}$ & 0.707 & 0.689 & .58471 & \\
\hline Sumber $:$ Data diolah, 2019 & & &
\end{tabular}

Berdasarkan Tabel 12. tersebut dapat diketahui bahwa nilai $r$ square $\left(\left(r^{2}\right)=\right.$ 0,707 Adapun analisis menggunakan rumus sebagai berikut:

$\mathrm{D}=\mathrm{r}^{2} \mathrm{x} 100 \%$

$\mathrm{D}=0,707 \times 100 \%$

$\mathrm{D}=70,7 \%$

Berdasarkan hasil tersebut diketahui bahwa nilai $\mathrm{R}^{2}=70,7$ persen, yang berarti bahwa sebesar 70,7 persen Produktivitas karyawan Di Jimbaran Bay Seafood Cafe dipengaruhi oleh variabel kompensasi $\left(\mathrm{X}_{1}\right)$, Disiplin kerja $\left(\mathrm{X}_{2}\right)$, dan Motivasi kerja (X3) dan sisanya sebesar 29,3 persen dipengaruhi oleh variabel lain yang tidak diteliti pada penelitian ini.

Tabel 13.

Hasil Uji F

\begin{tabular}{lllllll}
\hline Model & & Sum of Squares & Df & Mean Square & F & Sig. \\
\hline \multirow{3}{*}{1} & Regression & 42.001 & 3 & 14.000 & 40.951 & $0.000^{\mathrm{b}}$ \\
& Residual & 17.436 & 51 & 0.342 & & \\
& Total & 59.437 & 54 & & & \\
\hline
\end{tabular}

Sumber: Data diolah, 2019 
Berdasarkan hasil analisis, diketahui nilai signifikansi $\mathrm{F}$ adalah $0,000<0,05$, maka $\mathrm{H}_{0}$ ditolak. Hal ini berarti bahwa variabel Kompensasi $\left(\mathrm{X}_{1}\right)$, variabel Disiplin kerja $\left(\mathrm{X}_{2}\right)$, variabel Motivasi kerja $\left(\mathrm{X}_{3}\right)$, secara simultan berpengaruh signifikan terhadap produktivitas karyawan (Y) Di Jimbaran Bay Seafood Cafe, atau model yang digunakan dalam penelitian layak dan dapat dipergunakan untuk analisis berikutnya.

Tabel 14.

Hasil Uji t

\begin{tabular}{lll}
\hline Variabel & Unstandardized Coefficients Beta & Sig. \\
\hline Kompensasi & 0,305 & 0,008 \\
Disiplin kerja & 0,291 & 0,025 \\
Motivasi kerja & 0,346 & 0,005 \\
\hline
\end{tabular}

Sumber : Data diolah, 2019

Berdasarkan hasil analisis $\mathrm{di}$ atas dapat dijelaskan bahwa tingkat signifikansi $0,008<0,05$, sehingga $\mathrm{H}_{0}$ ditolak dan $\mathrm{H}_{\mathrm{a}}$ diterima yang berarti bahwa variabel Kompensasi berpengaruh positif signifikan terhadap Produktivitas karyawan. Koefisien regresi $\beta 1$ (variabel Kompensasi) sebesar 0,305, menunjukkan bahwa meningkatnya Kompensasi maka akan meningkatkan Produktivitas karyawan Di Jimbaran Bay Seafood Cafe. Berdasarkan hasil analisis di atas dapat dijelaskan bahwa tingkat signifikansi $0,025<0,05$, sehingga $\mathrm{H}_{0}$ ditolak dan $\mathrm{H}_{\mathrm{a}}$ diterima yang berarti bahwa variabel Disiplin kerja berpengaruh positif signifikan terhadap Produktivitas karyawan. Koefisien regresi $\beta 2$ (variabel Disiplin kerja) sebesar 0,291, menunjukkan bahwa meningkatnya Disiplin kerja maka akan meningkatkan Produktivitas karyawan Di Jimbaran Bay Seafood Cafe. Berdasarkan hasil analisis di atas dapat dijelaskan bahwa tingkat signifikansi $0,005<0,05$, sehingga $\mathrm{H}_{0}$ ditolak dan $\mathrm{H}_{\mathrm{a}}$ diterima yang berarti bahwa variabel Motivasi kerja berpengaruh positif signifikan terhadap Produktivitas karyawan. Koefisien regresi $\beta 3$ (variabel Motivasi kerja) sebesar 0,346, menunjukkan bahwa meningkatnya Motivasi kerja maka akan meningkatkan Produktivitas karyawan Di Jimbaran Bay Seafood Cafe.

Hasil pengujian menunjukkan kompensasi berpengaruh signifikan terhadap produktivitas perusahaan. Hasil yang signifikan tersebut disebabkan oleh adanya gaji yang dibayarkan setiap bulannya sesuai dengan produktivitas karyawan tersebut. Selain itu dukungan fasilitas yang didapatkan karyawan pada saat bekerja seperti pada bagian kitchen yaitu alat bakar yang memadai, tempat bekerja yang begitu nyaman dan tempat beristirahat yang nyaman yang dimana meningkatkan kenyamanan dan keselamatan kerja sehingga menyebabkan produktivitas menjadi lebih tinggi.

Hasil penelitian ini mengembangkan penelitian yang dilakukan oleh Putra \& Suana (2018) menyatakan bahwa kompensasi berpengaruh positif dan signifikan terhadap produktivitas karyawan pada Maya Ubud Resort \& Spa. Purwanto \& Wulandari (2016) menyatakan bahwa Kompensasi berpengaruh positif dan signifikan terhadap Produktivitas Kerja Karyawan pada PT. Pelangi. Agustini \& Dewi (2019) memperkuat penelitian dengan penelitian yang telah dilakukan yang menyatakan bahwa kompensasi berpengaruh positif dan signifikan terhadap 
produktivitas karyawan pada Single Fin Restaurant \& Bar Bali. Abdussamad (2014) juga memperkuat penelitian dengan penelitian yang telah dilakukan yang menyatakan bahwa kompensasi berpengaruh positif dan signifikan terhadap produktivitas karyawan pada PT. Sinar Galesong Pratama.

Santoni \& Suana (2018) mempertegas dalam penelitian yang telah dilakukan bahwa berdasarkan hasil analisis pengaruh kompensasi terhadap produktivitas kerja diperoleh pengaruh positif signifikan antara kompensasi terhadap produktivitas kerja yang berarti apabila kompensasi yang diberikan perusahaan baik maka produktivitas karyawan di Honda Denpasar Agung akan meningkat dan sebaliknya jika kompensasi yang diberikan perusahaan buruk maka produktivitas kerja karyawan di Honda Denpasar Agung akan menurun.

Hasil pengujian menunjukkan disiplin kerja berpengaruh signifikan terhadap produktivitas perusahaan. Hasil yang signifikan tersebut disebabkan oleh adanya peraturan yang sudah ditetapkan yang menyebabkan karyawan tidak pernah terlambat masuk kerja. Selain itu perintah yang diberikan oleh atasan langsung dikerjakan sehingga menyebabkan produktivitas menjadi lebih tinggi. Hasil penelitian ini mengembangkan penelitian yang dilakukan oleh Agustini \& Dewi (2019) menyatakan bahwa disiplin kerja berpengaruh positif dan signifikan terhadap produktivitas karyawan pada Single Fin Restaurant\&Bar Bali. Ruauw dkk. (2015) menyatakan bahwa disiplin kerja bepengaruh positif dan signifikan terhadap produktivitas pegawai pada Village Tingkulu Wanea districts of Manado. Abdussamad (2014) juga memperkuat penelitian dengan penelitian yang telah dilakukan yang menyatakan bahwa disiplin kerja berpengaruh positif dan signifikan terhadap produktivitas karyawan pada PT. Sinar Galesong Pratama. Ananta \& Adnyani (2016) mempertegas dalam penelitian yang telah dilakukan Variabel disiplin kerja berpengaruh positif dan signifnikan terhadap produktivitas kerja karyawan pada Villa Mahapala Sanur.

Hasil pengujian menunjukkan motivasi kerja berpengaruh signifikan terhadap produktivitas perusahaan. Hasil yang signifikan tersebut disebabkan oleh adanya keinginan karyawan untuk mendapatkan prestasi dalam bekerja dan pujian yang diterima atas apa yang dikerjakan menyebabkan produktivitas menjadi tinggi. Selain itu motivasi untuk mendapatkan insentif lebih tinggi dan memiliki rasa tanggung jawab yang tinggi atas pekerjaannya menyebabkan produktivitas menjadi lebih tinggi. Hasil penelitian ini mengembangkan penelitian yang dilakukan oleh Dewi \& Sudibya (2018) motivasi berpengaruh positif dan signifikan terhadap produktivitas karyawan di Hotel Natya Kuta. Putra \& Ardana (2016) menyatakan bahwa motivasi secara langsung berpengaruh positif dan signifikan terhadap kepuasan kerja perajin perak. Sudiardhita et al. (2018) memperkuat penelitian dengan penelitian yang telah dilakukan yang menyatakan bahwa motivasi berpengaruh positif dan signifikan terhadap produktivitas karyawan di PT. Artha Prima Finance Denpasar. Agustini \& Dewi (2019) mempertegas dalam penelitian yang telah dilakukan bahwa motivasi berpengaruh positif dan signifikan terhadap produktivitas karyawan di Single Fin Restaurant \& Bar Bali.

Implikasi teoritis dari hasil penelitin ini memberikan bukti pada pengembangan ilmu perilaku keorganisasian dan sumber daya manusia khususnya mengenai kompensasi, disiplin kerja, motivasi kerja dan produktivitas 
karyawan. Dengan demikian, hasil penelitian ini memberi dukungan empiris dan dapat dinyatakan memperkuat hasil-hasil studi terdahulu. Selain itu hasil penelitian ini secara praktis dapat menjadi salah satu acuan bagi peneliti lainnya yang ingin meneliti mengenai kompensasi, disiplin kerja, motivasi kerja dan produktivitas karyawan. Secara teoritis penelitian ini juga memberikan pemahaman bahwa kompensasi, disiplin kerja dan motivasi kerja secara nyata dapat meningkatkan produktivitas karyawan, dengan meningkatkan kompensasi, disiplin kerja dan motivasi kerja maka produktivitas karyawan akan mengalami peningkatan.

\section{SIMPULAN}

Berdasarkan hasil penelitian, maka dapat disimpulkan sebagai berikut: 1) Kompensasi berpengaruh positif dan signifikan secara parsial terhadap Produktivitas karyawan Di Jimbaran Bay Seafood Cafe. Hal ini berarti semakin tingginya kompensasi, maka akan meningkatkan Produktivitas karyawan. 2) Disiplin kerja berpengaruh positif dan signifikan secara parsial terhadap Produktivitas karyawan Di Jimbaran Bay Seafood Cafe. Hal ini berarti semakin tingginya Disiplin kerja, maka akan meningkatkan Produktivitas karyawan. 3) Motivasi kerja berpengaruh positif dan signifikan secara parsial terhadap Produktivitas karyawan Di Jimbaran Bay Seafood Cafe. Hal ini berarti semakin tingginya Motivasi kerja, maka akan meningkatkan Produktivitas karyawan.

Pihak manajemen di Jimbaran Bay Seafood Café harus tetap mempertahankan kompensasi, disiplin kerja dan motivasi kerja di dalam perusahaan agar karyawan merasa puas dan dapat berkomitmen terhadap perusahaan. Hal yang harus ditingkatkan adalah dari segi kompensasi, dalam kompensasi tunjangan yang diterima oleh karyawan, selain itu pemberian insentif karena karyawan telah menyelesaikan pekerjaan sesuai target begitu rendah. Selain itu dari segi disiplin kerja hal yang perlu ditingkatkan adalah tanggung jawab yang dimiliki oleh karyawan dan disiplin dalam mentaati peraturan dalam bekerja. Dari segi motivasi hal yang perlu ditingkatkan adalah perasaan ingin bersaing dari karyawan dengan cara memberikan hadiah atau reward bagi karyawan yang berprestasi. Bagi peneliti selanjutnya, diharapkan tidak hanya berpaku pada kompensasi, motivasi dan disiplin kerja, namun dapat menambah faktor-faktor lain yang mungkin mempengaruhi produktivitas karyawan, seperti lingkungan kerja, budaya organisasi dan pelatihan, selain itu menggunakan subjek penelitian lain seperti industri hospitality, manufaktur dan lain sebagiannya.

\section{REFERENSI}

Abdel-kader, M., \& Luther, R. (1018). An Empirical Investigation Of The An Empirical Investigation of the. JSES, 7(1), 1-31.

Abdussamad, Z. (2014). Pengaruh Kompensasi Terhadap Produktivitas Kerja Karyawan Pada PT Asuransi Jiwa Sraya Gorontalo. Jurnal Manajemen, 15(3), 456-466. 
Abomeh, P. (2015). Effects of Training on Employees' Productivity in Nigeria Insurance Industry. British Journal of Economics, Management \& Trade, 7(3), 227-235.

Agustini, N. K. I., \& Dewi, A. . S. K. (2019). Pengaruh Kompensasi, Disiplin Kerja dan Motivasi terhadap Produktivitas Karyawan. E-Jurnal Manajemen Unud, $8(1), 7191-7218$.

Ananta, I. K. F., \& Adnyani, I. G. A. D. (2016). Pengaruh Disiplin Kerja dan Budaya Organisasi terhadap Produktivitas Kerja Karyawan pada Villa Mahapala Sanur - Denpasar. E-Jurnal Manajemen Unud, 5(2), 2303-8912.

Bahri, B., \& Kamse, B. (2018). The Effect Of Islamic Leadership, Competence And Compensation On Work Dicipline And Teacher Performance Of Madrasah Aliyah In Makassar City. International Journal Of Scientific \& Technology Research, 7(12), 137-143.

Bawoleh, P., \& Tielung. (2015). The Effect Of Motivation And Compensation Toward Job Satisfaction In PT. SIG Asia Bitung. Jurnal EMBA, 3(3), 472481.

Dewi, P. A. C., \& Sudibya, I. G. A. (2018). Pengaruh Pelatihan, Motivasi dan Lingkungan Kerja Fisik terhadap Produktivitas Karyawan di Hotel Natya Kuta. E-Jurnal Manajemen Unud, 7(10), 5628-5656.

Dobre, O.-I. (2018). Employee motivation and organizational performance. Reaser, 5(2), 1286-1292. https://doi.org/10.1007/s11668-018-0520-7

Elingit, R. O., Obaga, B. K., \& Chemitei, L. J. (2019). Role of applying motivation theories on employee performance: A case of private school teachers in Busia township zone. European Journal of Research, 52(1), 46-52.

Emmywati, S., \& Fatimah. (2018). Performance Development: The Role Of Compensation And Work Discipline (Case of Directorate of Telecommunications Directorate General of Postal And Informatics Implementation in Jakarta). Academic Research International, 9(1), 97-108.

Maduka. (2014). Effect of Motivation on Employee Productivity: A Study of Manufacturing Companies in Nnewi. International Journal of Managerial Studies and Research (IJMSR) 2349-0349, 2(7), 137-147.

My, L. N. (2017). The Impact of Employees Motivation on Organizational Effectiveness. International Journal of Business And, 9(15), 134-145.

Negash, Z., \& Megersa. (2014). The Effect Of Compensation On Employees Motivation: In Jimma University Academic Staff. Basic Research Journal of Business Management and Accounts, 3(2), 17-27.

Okwudili, B. E., \& Ogbu, E. F. (2017). The Effect Of Compensation On Employee Performance In Negeria Civil Service: A Study Of Rivers State Board Of Internal Revenue Service. Journal of Strategic Human Resource 
Management, 6(2), 9-16.

Pawirosumarto, \& Muchtar. (2017). Factors Affecting Employee Performance of PT. Kiyokuni Indonesia. International Journal of Law and Management, 59(4), 1-25. https://doi.org/1108/IJLMA-03-2016-0031

Purwanto, A. B., \& Wulandari, O. (2016). Pengaruh Motivasi, Kompensasi dan Lingkungan Kerja terhadap Produktivitas Kerja Karyawan. Bulten Bisnis \& Manajemen, 2(1), 9-26.

Putra, A. A. G. K. P., \& Suana, I. W. (2018). Pengaruh Pelatihan dan Kompensasi terhadap Produktivitas Karyawan pada Hotel Maya Ubud Resort \& SPA. EJurnal Manajemen Unud, 7(9), 4971-4997.

Putra, I. M. W., \& Ardana, I. K. (2016). Pengaruh Motivasi Serta Lingkungan Kerja Terhadap Kepuasan Kerja Serta Dampaknya Terhadap Produktivitas Perajin Perak. E-Jurnal Manajemen Unud, 5(12), 7752-7784.

Rahardjo. (2017). The Effects of Compensation on Work Motivation: Evidence from Universities in Jakarta. International Journal of Economic Perspectives, 11(1), 1651-1662.

Ramzan, Z., \& Ali, A. (2014). Impact of Compensation on Employee Performance (Empirical Evidence from Banking Sector of Pakistan). International Journal of Business and Social Science, 5(2), 302-309.

Razak, S., \& Ramlan. (2018). Effect of Leadership Style, Motivation and Work Discipline on Employee Performance in PT. ABC Makassar. Econ Journals, 8(6), 67-71.

Ruauw, A. C. ., Lengkong, D., \& Mandey, J. (2015). Pengaruh Disiplin Kerja terhadap Produktivitas Pegawai (Suatu Studi di Kantor Kelurahan Tingkulu Kecamatan Wanea Kota Manado). JAP, 3(31), 1-10.

Santoni, N. P. C. C., \& Suana, I. W. (2018). Pengaruh Kompensasi, Motivasi, Disiplin Kerja terhadap Produktivitas Kerja Karyawan Divisi Sales di Honda Denpasar Agung. E-Jurnal Manajemen Unud, 7(10), 5379-5406.

Sudiardhita, M., Hartono, H., \& Sariwulan, N. (2018). The Effect Of Compensation, Motivation Of Employee and Work Satisfaction to Employee Performance PT. BANK XYZ (PERSERO) TBK. Academy of Strategic Management Journal, 17(4), 1-14. 